1 Title: Growth and mortality rates of prokaryotes in the hypolimnion of a deep

2 freshwater lake (Lake Biwa, Japan)

3

4 Hiroyuki Takasu $^{1^{*}}$, and Shin-ichi Nakano ${ }^{2}$

5

$6 \quad{ }^{1}$ Graduate School of Fisheries and Environmental Sciences,

$7 \quad$ Nagasaki University, 1-14 Bunkyo-machi, Nagasaki, 852-8521, Japan

$8{ }^{2}$ Center for Ecological Research (CER), Kyoto University, Hirano-cho 2 chome, 509-3,

9 Otsu, Shiga 520-2113, Japan

10

$11 *$ Correspondence author: Email takasu@nagasaki-u.ac.jp

12

13 Key words: Synechococcus, bacteria, protistan grazing, viral lysis, hypolimnion 
17 Abstract

18 The presence of pico-sized cyanobacteria (genus Synechococcus) in hypolimnetic waters

19 has been reported, and investigators have suggested that Synechococcus make a greater

20 contribution to ecological processes in the hypolimnion than previously hypothesized.

21 However, the ecological role of Synechococcus in food webs and/or matter cycling in the

22 hypolimnion remains unknown. To address this issue, we assessed protistan grazing and the

23 virus-mediated mortality of Synechococcus in the oxygenated hypolimnion of a large

24 freshwater lake (Lake Biwa, Japan) during the stratification period. In addition, we

25 compared the carbon flux through mortality of Synechococcus to that of heterotrophic

26 bacteria in order to evaluate the role of Synechococcus in ecological processes within a

27 hypolimnetic ecosystem. Our results suggest that the biomass of Synechococcus and

28 heterotrophic bacteria in the hypolimnion was removed primarily by protistan grazing. The

29 abundance of Synechococcus was highest in August, when the average

30 Synechococcus:bacteria carbon biomass and daily grazing loss ratios were 10.8 and 11.0\%,

31 respectively. Thus, it is likely that the Synechococcus biomass is an important seasonal

32 component of the carbon flux in the hypolimnetic microbial loop. Our results provide the

33 first data on carbon flux through the mortality of both Synechococcus and bacteria in a

34 hypolimnetic ecosystem. 
In deep freshwater lakes, the hypolimnion, which comprises a large proportion of the water mass, is separated from the epilimnion by the thermocline. The hypolimnion receives photosynthetically derived organic matter from the epilimnion in particulate form after substantial decomposition by heterotrophs. This organic matter flux is an important

food source for hypolimnetic vertebrate and invertebrate communities, and it sustains hypolimnetic ecosystems (Meyers and Ishiwatari 1993).

The widely distributed cyanobacterial genus Synechococcus is a major component of photosynthetic biomass in freshwater lakes (Sigee 2005). Synechococcus, which are among the smallest prokaryotes in phytoplankton communities, are vulnerable to microzooplankton grazing. Previous studies have suggested that most of their production is rapidly removed from the euphotic zone (Nagata 1988). Conversely, other researchers have reported the presence of pico-sized cyanobacteria in hypolimnetic waters (Callieri and Pinolini 1995, Takasu et al. 2015). Previously, we revealed that substantial numbers of intact Synechococcus cells were retained among larger organic particles that had sunk to the hypolimnion (Takasu et al. 2015). Thus, Synechococcus might be an important food source and/or item for hypolimnetic grazers. However, information about the fate of Synechococcus in a hypolimnetic ecosystem is limited, and the role of Synechococcus in food web and/or matter cycling remains unknown.

Protistan grazing and viral lysis are two important determinants of the fate of Synechococcus and heterotrophic bacteria (Sigee 2005). Protistan grazing transfers the prokaryotic biomass to organisms at higher trophic levels via the microbial loop, whereas viral lysis leads to the recycling of carbon and nutrients, each of which is derived from the lysed prokaryotic biomass and re-supplied to prokaryotes (Sigee 2005). Thus, it is important to characterize the relative contributions of grazing and lysis to Synechococcus 
61 mortality in order to understand their role in ecological processes in the hypolimnion. In the present study, we hypothesized that Synechococcus contributes to the food web and/or matter cycling in the oxygenated hypolimnion of Lake Biwa. To investigate this hypothesis, we assessed protistan grazing and virus-mediated Synechococcus mortality. To

65 evaluate the role of Synechococcus within the hypolimnetic ecosystem, we compared the carbon flux through Synechococcus mortality to that of bacteria.

\section{Study site}

Lake Biwa is a large (surface area, $674 \mathrm{~km}^{2}$; water volume, $27.3 \mathrm{~km}^{3}$; watershed area, $3848 \mathrm{~km}^{2}$ ), deep (maximum depth, $104 \mathrm{~m}$ ), tectonic, freshwater (average concentrations of $\mathrm{Cl}, \mathrm{Na}$ and $\mathrm{Ca}$ are 7.5, 5.2 and $10.4 \mathrm{mg} \mathrm{L}^{-1}$ 、respectively; Fujinaga et al. 2005) lake in Japan. The mesotrophic and monomictic north basin of the lake has a water residence time of 5.5 years. We collected water samples at station Ie-1 (35 $12^{\prime} 58^{\prime \prime} \mathrm{N}, 135^{\circ}$ 59 ' $55^{\prime \prime} \mathrm{E}$; $c a .75 \mathrm{~m}$ ) in the north basin of the lake. The water column is vertically mixed from January to March and stratified during the rest of the year.

\section{Methods}

Samples were collected on 19 May, 5 June, 11 August, and 27 August 2015 during the stratification period. Vertical profiles of water temperature and light intensity were determined using a CTD probe (SBE 911 Plus; Sea Bird Electronics, Bellevue, WA, USA). Water samples were collected using Niskin X bottles.

To determine chlorophyll $a(\mathrm{chl} a)$ concentrations, water samples of $285 \mathrm{ml}$ collected at depths of $5 \mathrm{~m}$ (epilimnion) and $65 \mathrm{~m}$ (hypolimnion) were filtered through $0.2-$ and 2.0- $\mu \mathrm{m}$ polycarbonate filters (Whatman International, Ltd., Maidstone, England) and analyzed by fluorometry (Fluorometer 10-AU; Turner Designs, Sunnyvale, CA, USA) according to Welschmeyer (1994). Chl $a$ concentrations in the $0.2-2.0-\mu \mathrm{m}$ fraction 
(hereafter, the "pico-sized fraction") were calculated according to Takasu et al. (2015).

Samples for microbial enumeration were collected at $65 \mathrm{~m}$ then fixed immediately with glutaraldehyde (Wako Pure Chemical Industries, Osaka, Japan; final concentration: $1 \%$, vol/vol) and stored at $4{ }^{\circ} \mathrm{C}$ in the dark until the preparation of microscope slides. For enumeration of Synechococcus, fixed water samples of 15 to $40 \mathrm{~mL}$ were filtered through 0.2- $\mu \mathrm{m}$-pore-size black polycarbonate filters (Advantec, Tokyo, Japan). Phycoerythrin (PE)-rich Synechococcus, the most abundant picophytoplankton in the lake $(>99 \%$ of Synechococcus in the hypolimnion; Takasu et al. 2015), were counted using an optical setting for PE (U-MNIB2; Olympus, Tokyo, Japan). At least 300 cells or 100 fields were counted to estimate cell abundance.

From the fixed water sample, $1 \mathrm{~mL}$ was used for the enumeration of bacteria. Bacterial cells were stained with 4',6-diamidino-2-phenylindole (DAPI; Wako Pure Chemical Industries; final concentration: $10 \mu \mathrm{g} \mathrm{mL} \mathrm{L}^{-1}$ ) for $10 \mathrm{~min}$, filtered on black-stained 0.2- $\mu$ m-pore-size black polycarbonate filters (Advantec), and counted under an epifluorescence microscope (BX61; Olympus) (Porter and Feig 1980) using an optical setting for DAPI (U-MWU2; Olympus). At least 300 bacterial cells were counted within a minimum of 20 randomly selected fields.

From the fixed water sample, $15 \mathrm{~mL}$ were used for the enumeration of heterotrophic nanoflagellates $(\mathrm{HNF})$, and $0.1 \mathrm{~mL}\left(1 \mathrm{~mL}\right.$ from samples diluted $10^{9}$ with $0.02-\mu \mathrm{m}$-filtered distilled water) was used for the enumeration of viral-like particles (VLP). HNF were double-stained with DAPI (final concentration: $10 \mu \mathrm{g} \mathrm{mL}^{-1}$ ) and fluorescein isothiocyanate (Dojindo Molecular Technology, Inc., Rockville, MD, USA; final concentration: $10 \mu \mathrm{g}$ $\mathrm{mL}^{-1}$ ) for $10 \mathrm{~min}$, collected on $0.8-\mu \mathrm{m}$-pore-size black polycarbonate filters (Whatman), and counted using epifluorescence microscopy under ultraviolet (UV; U-MWU2; Olympus) and blue (IB-NIB; Olympus) excitation according to Sherr and Sherr (1983). For HNF counting, a minimum of 100 randomly selected fields were inspected. VLP were counted 
using epifluorescence microscopy under blue excitation by the SYBR Green I (Molecular Probes Inc., Eugene, OR, USA; final concentration: $5 \times 10^{-5}$ dilution of commercial stock; 30 min of incubation) method (Patel et al. 2008) using 0.02- $\mu$ m-pore-size Anodisc filters (Whatman; GE Healthcare, Wauwatosa, WI, USA). More than 300 VLP were counted, and a minimum of 10 randomly selected fields were examined.

The length and width of Synechococcus, bacteria, and HNF cells were measured in each sample using image analysis software (ImageJ; National Institutes of Health, Bethesda, MD, USA). Images were captured at a magnification of $1,000 \times$ with a charge-coupled device camera (DP70; Olympus). The Synechococcus, bacteria and HNF cell volume was calculated by assuming that the cells were spherical. The carbon biomass of Synechococcus, bacteria, and HNF was determined by combining the cell volume data with a carbon conversion factor estimated for both unicellular cyanobacteria and bacteria in this lake (106 fg $\mathrm{C} \mu \mathrm{m}^{-3}$; Nagata 1986) and HNF (71 fg $\mathrm{C} \mu \mathrm{m}^{-3}$; Fenchel and Finlay 1983). Equivalent spherical diameters (ESDs) were calculated according to Hansen et al. (1994).

For the dilution experiments, approximately $5 \mathrm{~L}$ of lake water were collected at a depth of $65 \mathrm{~m}$ then were gently filtered through a $1.2 \mathrm{M} \mathrm{HCl}$-washed $20-\mu \mathrm{m}$ nylon mesh to remove mesozooplankton. In Lake Biwa, it has been reported that the ciliates are not important grazers of prokaryotes, and that the main grazers of prokaryotes are HNF (Nakano et al. 1998, Sekino et al. 2007). Thus, we used $20-\mu \mathrm{m}$ mesh for pre-filtration, though this filtration step may remove ciliates. A 1-L portion of the filtrate was passed through a $0.2-\mu \mathrm{m}$-pore-size polyether sulphone ultrafiltration membrane (Vivaflow200; Sartorius, Göttingen, Germany) equipped with a peristaltic pump (Masterflex Tubing Pump System L/S; Masterflex, Gelsenkirchen, Germany) and collected into 1-L polycarbonate bottles washed with 1.2 $\mathrm{M} \mathrm{HCl}$ before use. After the filtration, half of the $0.2-\mu \mathrm{m}$ filtrate was passed through a $30-\mathrm{kDa}$ polyether sulphone ultrafiltration membrane (Vivaflow200; Sartorius) to prepare a grazer-and-virus-free diluent. The ultrafiltration membranes were 
cleaned before use with $0.5 \mathrm{mM} \mathrm{NaOCl} / 0.5 \mathrm{M} \mathrm{NaOH}$.

The $20-\mu \mathrm{m}$ filtrate was diluted in $0.2-\mu \mathrm{m}$ or $30-\mathrm{kDa}$ diluent to dilution levels of 1.0 , $0.8,0.6,0.4,0.2$, and 0.1 in $250-\mathrm{mL}$ polycarbonate bottles washed with $1.2 \mathrm{M} \mathrm{HCl}$ before use. The dilution level of 0.1 was not prepared for May and June. The bottles were then incubated for 36-48 $\mathrm{h}$ at in situ temperatures in the dark. Subsamples for the enumeration of Synechococcus were collected at the beginning $(0 \mathrm{~h})$ and end of the incubations, fixed immediately with glutaraldehyde (final concentration: $1 \%$, vol/vol), and stored at $4^{\circ} \mathrm{C}$ in the dark until the preparation of microscope slides. During sample collection and handling, gloves were worn and care was taken to minimize contamination.

The apparent growth rates $\left(\mu_{\mathrm{app}}, \mathrm{d}^{-1}\right)$ of bacteria and Synechococcus were calculated from their cell abundances at the beginning and end of the incubation experiment, with the assumption that bacterial and Synechococcus growth would follow an exponential model (Landry and Hassett 1982):

$$
\mu_{\text {app }}=(1 / t) \ln \left(N_{t} / N_{0}\right)
$$

where $t$ is the duration of incubation (days), and $N_{0}$ and $N_{\mathrm{t}}$ are the abundances of Synechococcus or bacteria (cells $\mathrm{mL}^{-1}$ ) at the beginning and end of the incubation, respectively. Two dilution series were prepared: a $30-\mathrm{kDa}$ dilution series to estimate the combined effects of the protistan grazing and viral lysis rates $\left(g+v, \mathrm{~d}^{-1}\right)$ and a $0.2-\mu \mathrm{m}$ dilution series to determine the effect of the protistan grazing rate $\left(g, \mathrm{~d}^{-1}\right)$ on Synechococcus and bacteria. The slope of the regression lines from the $0.2-\mu \mathrm{m}$ dilution series represents the grazing rate. The difference between the slopes of the regression lines represents the bacterial mortality rate due to viral lysis $\left(v, \mathrm{~d}^{-1}\right)$; this difference was tested using an analysis of covariance (ANCOVA). The intercept of the $30-\mathrm{kDa}$ dilution series provides the instantaneous growth rate $\left(\mu, \mathrm{d}^{-1}\right)$ of Synechococcus and bacteria in the absence of grazing 
or viral lysis (Evans et al. 2003).

The carbon flux through mortality of Synechococcus and bacteria was estimated by combining data from the dilution experiments with carbon conversion factors estimated

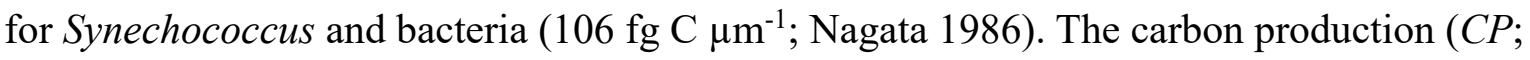
$\left.\mu \mathrm{g} \mathrm{C} \mathrm{L}^{-1} \mathrm{~d}^{-1}\right)$ and losses to grazing $\left(G L ; \mu g \mathrm{C} \mathrm{L}^{-1} \mathrm{~d}^{-1}\right)$ were calculated using the following formulas:

where $\mu\left(\mathrm{d}^{-1}\right)$ is the dilution-based specific growth (y-intercept of the $0.2-\mu \mathrm{m}$ regression, see Results), $g$ is the dilution-based grazing rate (in $\mathrm{d}^{-1}$ ), and $P_{0}\left(\right.$ in $\mu \mathrm{g} \mathrm{C} \mathrm{L}^{-1}$ ) is the initial carbon biomass of Synechococcus or bacteria.

All statistical analyses were performed using the free statistical environment $R$ ( $R$ Development Core Team 2015).

\section{Results}

The euphotic depth $\left(Z_{1 \%}\right)$ did not exceed $25 \mathrm{~m}$ throughout the study period, indicating that below this depth was the aphotic layer (Table 1). The contributions of the pico-sized fraction to the total chl $a$ concentration at 5 and $65 \mathrm{~m}$ were $42.3 \pm 11 \%$ (average $\pm \mathrm{SD}$ ) and $14.3 \pm 3.3 \%$, respectively (Table 1). The cellular abundance of Synechococcus at a depth of $65 \mathrm{~m}$ increased markedly from June $\left(0.47 \times 10^{3}\right.$ cells $\left.\mathrm{mL}^{-1}\right)$ to August $(2.83 \times$ $10^{3}$ cells $\mathrm{mL}^{-1}$; Table 2 ). In contrast, the abundances of bacteria, HNF, and VLP were relatively constant throughout the study period (Table 2). The ESD of Synechococcus $(1.33-1.62 \mu \mathrm{m})$ was about three times larger than that of bacteria $(0.46-0.60 \mu \mathrm{m}$; Table 2$)$ 
throughout the study period. The ESD of HNF was 4.77-5.24 $\mu \mathrm{m}$ (Table 2).

In three out of the four experiments, there was a significant relationship between the apparent growth rate of Synechococcus or bacteria and the level of dilution in both the $0.2-\mu \mathrm{m}$ and $30-\mathrm{kDa}$ dilution series (Table 3). However, there was no significant difference (ANCOVA, $P>0.1$ ) between the regression slopes of the $0.2-\mu \mathrm{m}$ and $30-\mathrm{kDa}$ dilution series in any experiment (Table 3). Owing to these results, the growth rate could not be determined from the $30-\mathrm{kDa}$ and virus-mediated mortality rates.

The growth rate $(\mu)$ of Synechococcus and bacteria in the absence of protistan grazing ranged from $-0.200( \pm \mathrm{SE} ; 0.045)$ to $-0.007( \pm \mathrm{SE} ; 0.115)$ and from $0.053( \pm \mathrm{SE}$; $0.080)$ to $0.502( \pm \mathrm{SE} ; 0.846)$, respectively (Table 3$)$. The grazing mortality rates $(g)$ of Synechococcus and bacteria varied from $0.382( \pm \mathrm{SE} ; 0.078)$ to $0.616( \pm \mathrm{SE} ; 0.174)$ and from $0.305( \pm \mathrm{SE} ; 0.131)$ to $0.846( \pm \mathrm{SE} ; 0.293)$, respectively (Table 3$)$. High rates of grazing mortality among bacteria tended to be accompanied by a high bacterial growth rate (Table 3).

The Synechococcus carbon biomass and loss to protistan grazing were $0.06-0.66$

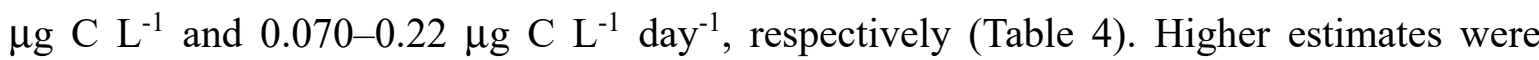
obtained from samples taken during the period of high Synechococcus abundance (August; Fig. 1). Daily carbon losses from grazing accounted for 33.4-61.6\% (average \pm SD: $44.3 \pm$ $15.1 \%$ ) of the Synechococcus biomass. The bacterial carbon biomass and loss to protistan grazing were higher than those of Synechococcus, ranging from 3.10 to $9.78 \mu \mathrm{g} \mathrm{C} \mathrm{L} \mathrm{L}^{-1}$ versus 0.94 to $3.98 \mu \mathrm{g} \mathrm{C} \mathrm{L}^{-1}$ day $^{-1}$, respectively (Table 4).

\section{Discussion}

We applied the modified dilution technique to estimate the growth and mortality rates of prokaryotes in the hypolimnion of a lake. We did not find significant differences 
between the $0.2-\mu \mathrm{m}$ and $30-\mathrm{kDa}$ regressions (Table 3 ). It has been suggested that viral lysis

218 rates $<0.1 \mathrm{~d}^{-1}$ are difficult to detect using the modified dilution method (Kimmance and

219 Brussaard 2010). Thus, our failure to detect viral lysis rates suggests that they were $<0.1$ $\mathrm{d}^{-1}$. Indeed, Pradeep Ram et al. (2010) found a low frequency of bacterial cells infected by viruses in the hypolimnion of Lake Biwa, suggesting that this is the norm. In any case, the effects of viral lysis on the growth rates of Synechococcus and heterotrophic bacteria may be negligible in the present study, though we could not estimate growth rates from the $\mathrm{y}$-intercepts of the $30-\mathrm{kDa}$ regressions.

In the present study, we detected high grazing mortality rates of Synechococcus and bacteria, whereas the viral lysis rates were negligible (Table 3). This finding suggests that protistan grazing plays a key role in the removal of prokaryotic cells from the hypolimnion of Lake Biwa.

In the present study, bacterial growth and grazing mortality rates were positively correlated $(r=0.961, P<0.05)$, suggesting that bacterial grazing mortality depends on bacterial production in the hypolimnion. On the other hand, Synechococcus did not proliferate and showed different grazing rates among experiments (Table 3). This result HNF and bacteria was $10.0 \pm 0.43$ (average \pm SD). Because the observed HNF:prey size 
inappropriate food particles for HNF in the hypolimnion. Thus, it is likely that the principal factor controlling the Synechococcus biomass differs from that of bacteria in the hypolimnion.

Positive relationships between viral lysis and host growth have been reported for both bacteria (Weinbauer et al. 2003) and Synechococcus (Pasulka et al. 2015). We also found the positive relationships between viral lysis and bacterial growth in the epilimnion of Lake Biwa (Takasu et al. 2014). In the present study, however, viral lysis remained low in the hypolimnion. Personnic et al. (2009) suggested that viruses could have a long latent period (more than $48 \mathrm{~h}$ ) when bacterial activity is low during cold winter season (4.2 to $11.8^{\circ} \mathrm{C}$ ) in three peri-alpine lakes. Because the hypolimnion of Lake Biwa has a constant cold temperature $\left(8^{\circ} \mathrm{C}\right)$ throughout the stratification period, the latent period of hypolimnetic viruses may be longer than the duration of our incubation experiments (36-48 h). In addition, it is likely that high oxygen concentration in the hypolimnion of Lake Biwa does not inhibit HNF grazing activity (Pradeep Ram et al. 2010), and most of bacterial cells were consumed by HNF grazing before lysed by viruses.

In addition, the low viral lytic pressure on Synechococcus in the present study might be attributable to a state of inactivity or dormancy among Synechococcus in the hypolimnion. Although viral lysis rate of Synechococcus in the epilimnion is not available, a previous study suggested that the cyanophages are not important components of viral communities in Lake Biwa (Pradeep Ram et al. 2010). Thus, viral lysis is likely to be minor as a mortality source for Synechococcus throughout water column of Lake Biwa.

Despite low viral lytic pressure on prokaryotes, the range of virus-to-prokaryote abundance ratios (VPRs) were 11.9-28.5 in the hypolimnion, falling within the range of the epilimnion (Takasu et al. 2014). In addition to host abundance and growth rate, factors that decrease the viral population may also account for the observed VPR, since viral populations are determined by both viral production and decay. Previous studies 
demonstrated that several processes are involved in the removal of viruses from water columns in the surface layer, including extracellular proteases and high UV radiation (Sigee 2005). The low extracellular protease activity and absence of UV radiation in the hypolimnion (Kim et al. 2007) may allow VPRs similar to those in the epilimnion, owing to the relatively low rate of viral decay.

In the present study, the contribution of the pico-sized fraction to the total $\operatorname{chl} a$ concentration in the hypolimnion (average $\pm \mathrm{SD}: 14.3 \pm 3.3 \%$; Table 1) reinforces the importance of Synechococcus as an organic matter transporter in Lake Biwa (Takasu et al. 2015). The Synechococcus-to-bacteria carbon biomass ratio ( $\left.\mathrm{Syn}_{\mathrm{cB}} / \mathrm{Bac}_{\mathrm{CB}}\right)$ and daily grazing loss ratio (SyngL/Bac $\left.{ }_{G L}\right)$ were high in August $(10.8 \pm 0.3$ and $11.0 \pm 4.0 \%$, respectively; Table 5). Thus, it is likely that the Synechococcus biomass is an important seasonal component of the carbon flux in the hypolimnetic microbial loop (Fig. 1). However, the highest Synechococcus abundance in the present study (maximum: $2.8 \times 10^{3}$ cells $\mathrm{mL}^{-1}$ ) was lower than that observed in our hypolimnion monthly monitoring efforts in 2011 (maximum: $2.4 \times 10^{4}$ cells $\mathrm{mL}^{-1}$; Takasu et al. 2015) and 2010 (maximum: $4.4 \times 10^{4}$ cells $\mathrm{mL}^{-1}$; author's unpublished data). Our estimates of SyncB/BaccB and SynGL/BacGL in the present study may be conservative with respect to the contribution of Synechococcus to the carbon flux in the hypolimnion of Lake Biwa. Although we do not know the reason why Synechococcus abundance was low during the present study period, transportation of the epilimnetic Synechococcus abundance may largely affects the abundance of the hypolimnteic Synechococcus.

Although high protistan grazing pressure on Synechococcus has been reported in natural aquatic systems (Christaki et al. 2001), previous laboratory studies suggested that Synechococcus is a low-quality component of the protistan diet (Caron et al. 1991). Apple et al. (2011) evaluated Synechococcus as a food source for different protist grazers. They found that the suitability of Synechococcus varied among protistan taxa, and that 
Synechoccus may be a viable food source for small protists such as colorless cryptomonads (6-8 $\mu \mathrm{m}$ in diameter). Thus, the biomass of Synechococcus in the hypolimnion may contribute to the hypolimnetic food web via the microbial loop. Additional grazing experiments conducted using major HNF taxa in the hypolimnion (e.g., kinetoplastids; Mukherjee et al. 2015) and Synechococcus will enhance our understanding of the role of Synechococcus in the carbon flux of the hypolimnion.

Our current understanding of the fate of prokaryotes is based mainly on research conducted in the surface layer. The incorporation of hypolimnetic microbial processes into ecological and biogeochemical models of freshwater lakes has been largely hampered by limitations to our knowledge regarding the fate of prokaryotes in the hypolimnion. The present study is the first to provide data regarding carbon flux through the mortality of prokaryotes (Synechococcus and bacteria) in a hypolimnetic ecosystem.

\section{Acknowledgements}

We would like to thank Dr. Yukiko Goda and Prof. Yoshikuni Hodoki for their assistance during the field sampling period. This study was supported in part by the ESPEC Foundation for Global Environment Research and Technology (H.T.). H.T. was also supported by JSPS KAKENHI Grant Number 15J06912.

\section{References}

Apple JK, Strom SL, Palenik B, Brahamsha B. 2011. Variability in protist grazing and growth on different marine Synechococcus Isolates. Appl. Environ. Microbiol. $77: 3074-3084$.

Callieri C, Pinolini ML. 1995. Picoplankton in Lake Maggiore, Italy. Int. Revue. ges. Hydrobiol. 80:491-501.

Caron DA, Lim EL, Miceli Geraldine, Waterbury JB, Frederica WV. 1991. Grazing and 
utilization of chroococcoid cyanobacteria and heterotrophic bacteria by protozoa in laboratory cultures and a coastal plankton community. Aquat. Microb. Ecol. $76: 205-217$.

Christaki U, Giannakourou A, Wambeke FV, Grégori G. 2001. Nanoflagellate predation on auto- and heterotrophic picoplankton in the oligotrophic Mediterranean Sea. J. Plankton Res. 23:1297-1310.

Evans C, Archer SD, Jacquet S, Wilson WH. 2003. Direct estimates of the contribution of viral lysis and microzooplankton grazing to the decline of a Micromonas spp. population. Aquat. Microb. Ecol. 30:207-219.

Fujinaga T, Sohrin Y, Isshiki K (2005) Umi to Mizuumi no Kagaku. [Chemistry of the oceans and lakes.]. Kyoto University Press, Kyoto (in Japanese)

Fenchel T, Finlay BJ. 1983. Respiration rates in heterotrophic, free-living protozoa. Microb. Ecol. 30:99-122.

Gonzalez JM, Sherr EB, Sherr BF. 1990. Size- selective grazing on bacteria by natural assemblages of estua- rine flagellates and ciliates. Appl. Environ. Microbiol. $56: 583-589$.

Hansen B, Bjornsen PK, Hansen PJ. 1994. The size ratio between planktonic predators and their prey. Limnol. Oceanogr. 39:395-403.

Kim C, Nishimura Y, Nagata T. 2007. High potential activity of alkaline phosphatase in the benthic nepheloid layer of a large mesotrophic lake: implications for phosphorus regeneration in oxygenated hypolimnion. Aquat. Microb. Ecol. 49:303-311.

Kimmance SA, Brussaard CPD. 2010. Estimation of viralinduced phytoplankton mortality using the modified dilution method. In: Wilhelm SW, Weinbauer MG, Suttle CA, editors. Manual of Aquatic Viral Ecology. American Society of Limnology and Oceanography. p 65-73.

Landry MR, Hassett RP. 1982. Estimating the grazing impact of marine micro-zooplankton. 
Marine Biol. 67:283-288.

Meyers PA, Ishiwatari R. 1993. Lacustrine organic geochemistry-an overview of indicators of organic matter sources and diagenesis in lake sediments. Org. Geochem. 20:867-900.

Mukherjee I, Hodoki Y, Nakano S. 2015. Kinetoplastid flagellates overlooked by universal primers dominate in the oxygenated hypolimnion of Lake Biwa, Japan. FEMS Microbiol. Ecol. 91:fiv083.

Nagata T. 1986. Carbon and nitrogen content of natural planktonic bacteria. Appl. Environ. Microbiol. 52:28-32.

Nagata T. 1988. The microflagellate-picoplankton food linkage in the water column of Lake Biwa. Limnol. Oceanogr. 33:504-517.

Nakano S, Koitabashi T, Ueda T. 1998. Seasonal changes in abundance of heterotrophic nanoflagellates and their consumption of bacteria in Lake Biwa with special reference to trophic interactions with Daphnia galeata. Arch. Hydrobiol. 142:21-34.

Pasulka AL, Samo TJ, Landry MR. 2015. Grazer and viral impacts on microbial growth and mortality in the southern California Current Ecosystem. J. Plankton Res. 37:1-17.

Patel A, Nobel RT, Steele JA, Schwalbach MS, Hewson I, Fuhrman JA. 2008. Virus and prokaryote enumeration from planktonic aquatic environments by epifluorescence microscopy with SYBR Green I. Nat. Protoc. 2:269-276.

Personnic S, Domaizon I, Sime-Ngando T, Jacquet S. 2009. Seasonal variations of microbial abundances and virus- versus flagellate- induced mortality of picoplankton in three peri-alphine lakes. J. Plankton Res, 31:1161-1177.

Pradeep Ram AS, Nishimura Y, Tomaru Y, Nagasaki K, Nagata T. 2010. Seasonal variation in viral-induced mortalityof bacterioplankton in the water column of a large mesotrophic lake (Lake Biwa, Japan). Aquat. Microb. Ecol. 58:249-259.

Porter KG, Feig YS. 1980. The use of DAPI for identifying and counting aquatic microflora. 
Limnol. Oceanogr. 25:943-948.

R Development Core Team. 2015. R: a language and environment for statistical computing. R Development Core Team, Vienna

Sekino T, Genkai-Kato M, Kawabata Z, Melnik NG, Logacheva NP, Belykh OI, Obolkina LA, Bondarenko NA, Khodzher TV, Gorbunova LA, Tanichev AI, Yoshida T, Kagami M, Gurung TB, Urabe J, Higashi M, Nakanishi M. 2007. Role of phytoplankton size distribution in lake ecosystems revealed by a comparison of whole plankton community structure between Lake Baikal and Lake Biwa. Limnology 8:227-232.

Sherr B, Sherr E. 1983. Enumeration of heterotrophic microprotozoa by epifluorescence microscopy. Est. Coast Self Sci. 16:1-7.

Sigee DC. 2005. Freshwater microbiology: Biodiversity and dynamic interactions of microorganisms in the aquatic environment. England: John Wiley \& Sons.

Takasu H, Kunihiro T, Nakano S. 2014. Protistan grazing and viral lysis losses of bacterial carbon production in a large mesotrophic lake (Lake Biwa). Limnology 15: 257-270.

Takasu H, Ushio M, LeClair J, Nakano S. 2015. High contribution of Synechococcus to phytoplankton biomass in the aphotic hypolimnion in a deep freshwater lake (Lake Biwa, Japan). Aquat. Microb. Ecol. 75:69-79.

Weinbauer MG, Christaki U, Nedoma J, Šimek K. 2003. Comparing the effects of resource enrichment and grazing on viral production in a meso-eutrophic reservoir. Aquat. Microb. Ecol. 31:137-144.

Welschmeyer NA. 1994. Fluorometric analysis of chlorophyll-a in the presence of chlorophyll-b and pheopigments. Limnol. Oceanogr. 398:1985-1992. 
Table and Figures

397

398

Table 1. Temperature, euphotic depth $\left(\mathrm{Z}_{1 \%}\right)$ and chlorophyll $a(\mathrm{Chl} a)$ in the epi- and hypolimnion of Lake Biwa during the stratification period.

400

401

402

403

404

405 mortality $(m+v)$ of Synechococcus (A) and bacteria (B) from the dilution experiments.

406

407

408

409 and bacteria.

410

411 412 ratio $\left(\mathrm{Syn}_{\mathrm{GL}} / \mathrm{Bac}_{\mathrm{GL}}\right)$.

Table 5. Synechococcus-to-bacteria carbon biomass ratio (Syncв/BaccB) and grazing loss

413

414 Fig. 1 Carbon flow in May and June (A) and August (B). S, B, H, V denote Synechococcus, 415 bacteria, heterotrophic nanoflagellates, and viruses, respectively. Numerical numbers 416 indicate carbon biomass or carbon flow through grazing mortality. n.a., not available. 
417 Table 1

\begin{tabular}{rrrrrrr}
\hline Date (day/mo/yr) & $\mathrm{Z}_{1 \%}(\mathrm{~m})$ & Depth $(\mathrm{m})$ & $\begin{array}{c}\text { Water temp. } \\
\left({ }^{\circ} \mathrm{C}\right)\end{array}$ & $\begin{array}{c}\text { Chl } a \\
\left(\mu \mathrm{g} \mathrm{L}^{-1}\right)\end{array}$ & $\begin{array}{r}\text { Pico-Chl } a^{a} \\
\left(\mu \mathrm{g} \mathrm{L}^{-1}\right)\end{array}$ & $\begin{array}{r}\text { Pico-Chl } a^{b} \\
(\%)\end{array}$ \\
\hline $19 / 05 / 2015$ & 25.0 & 5 & 16.7 & 2.20 & 1.08 & 49.1 \\
& & 65 & 7.2 & 0.16 & 0.02 & 12.5 \\
$05 / 06 / 2015$ & 21.8 & 5 & 19.8 & 2.17 & 0.69 & 31.7 \\
& & 65 & 7.5 & 0.11 & 0.02 & 18.2 \\
$11 / 08 / 2015$ & 19.0 & 5 & 29.5 & 1.30 & 0.70 & 53.8 \\
& & 65 & 7.4 & 0.13 & 0.02 & 12.3 \\
$27 / 08 / 2015$ & 16.5 & 5 & 26.6 & 2.77 & 0.93 & 33.6 \\
& & 65 & 7.5 & 0.08 & n.d. & n.a.
\end{tabular}

$418{ }^{a}$ Pico-sized fraction chl $a$ (see Methods)

$419{ }^{b}$ Contribution of pico-sized fraction to total chl $a$

420 n.d., not determined; n.a., not available. 
423 Table 2

\begin{tabular}{|c|c|c|c|c|c|c|c|c|c|c|c|}
\hline & Depth & Synechococcus & & & Bacteria & & & $\mathrm{HNF}$ & & & VLPs \\
\hline $\begin{array}{c}\text { Date } \\
\text { (day/mo/yr) }\end{array}$ & (m) & $\begin{array}{l}\text { Cell number } \\
\begin{array}{c}\left(10^{3} \text { cells }\right. \\
\left.\mathrm{mL}^{-1}\right)\end{array}\end{array}$ & $\begin{array}{l}\text { Cell volume } \\
\left(\mu \mathrm{m}^{3} ; \text { Mean } \pm\right. \\
\mathrm{SD})\end{array}$ & $\begin{array}{c}\text { ESD } \\
(\mu \mathrm{m} ; \text { Mean } \pm \\
\text { SD) }\end{array}$ & $\begin{array}{l}\text { Cell number } \\
\left(10^{5} \text { cells }\right. \\
\left.\mathrm{mL}^{-1}\right)\end{array}$ & $\begin{array}{l}\text { Cell volume } \\
\left(\mu \mathrm{m}^{3} ; \text { Mean } \pm\right. \\
\mathrm{SD})\end{array}$ & $\begin{array}{c}\text { ESD } \\
(\mu \mathrm{m} ; \text { Mean } \pm \\
\text { SD }\end{array}$ & $\begin{array}{l}\text { Cell number } \\
\left(10^{2} \text { cells }\right. \\
\left.\mathrm{mL}^{-1}\right)\end{array}$ & $\begin{array}{l}\text { Cell volume } \\
\left(\mu \mathrm{m}^{3} ; \text { Mean } \pm\right. \\
\mathrm{SD})\end{array}$ & $\begin{array}{c}\text { ESD } \\
(\mu \mathrm{m} ; \text { Mean } \pm S D\end{array}$ & $\begin{array}{c}\text { Particle number } \\
\left(10^{7} \text { particles }\right. \\
\left.\mathrm{mL}^{-1}\right)\end{array}$ \\
\hline $19 / 05 / 2015$ & 65 & 0.47 & $1.26 \pm 1.81$ & $1.33 \pm 0.51$ & 8.9 & $0.050 \pm 0.122$ & $0.46 \pm 0.24$ & 1.5 & $77.2 \pm 288$ & $5.20 \pm 2.56$ & 1.6 \\
\hline $05 / 06 / 2015$ & 65 & 0.47 & $2.28 \pm 1.30$ & $1.63 \pm 0.31$ & 8.4 & $0.109 \pm 0.162$ & $0.60 \pm 0.24$ & 1.1 & $79.6 \pm 68.3$ & $5.24 \pm 1.48$ & 1.5 \\
\hline $11 / 08 / 2015$ & 65 & 2.83 & $2.18 \pm 2.39$ & $1.60 \pm 0.48$ & 9.2 & $0.064 \pm 0.505$ & $0.50 \pm 0.28$ & 1.8 & $59.6 \pm 42.0$ & $4.77 \pm 1.26$ & 1.1 \\
\hline $27 / 08 / 2015$ & 65 & 1.44 & $2.24 \pm 1.73$ & $1.62 \pm 0.43$ & 5.6 & $0.052 \pm 0.137$ & $0.47 \pm 0.23$ & 1.2 & $66.2 \pm 56.2$ & $4.94 \pm 1.21$ & 1.6 \\
\hline
\end{tabular}

424 ESD, Equivalent spherical diameter 


\section{Table 3}

(A) Synechococcus

\begin{tabular}{|c|c|c|c|c|c|c|c|c|c|c|c|c|}
\hline \multirow[b]{2}{*}{ (day/mo/yr) } & \multirow{2}{*}{ Diluent } & \multirow{2}{*}{$\begin{array}{c}\text { Dilution } \\
\text { level }\end{array}$} & \multicolumn{2}{|c|}{ Linear fit } & \multirow{2}{*}{$\begin{array}{c}\text { Regresion } \\
\text { slopes } \\
p\end{array}$} & \multirow{2}{*}{$\mu$} & \multirow{2}{*}{$\pm \mathrm{SE}$} & \multirow{2}{*}{$g$} & \multirow{2}{*}{$\pm \mathrm{SE}$} & \multirow{2}{*}{$v$} & \multirow{2}{*}{$g+v$} & \multirow{2}{*}{$\pm \mathrm{SE}$} \\
\hline & & & $r^{2}$ & $p$ & & & & & & & & \\
\hline \multirow[t]{2}{*}{$19 / 05 / 2015$} & $0.2 \mu \mathrm{m}$ & & 0.611 & n.s. & \multirow[b]{2}{*}{ n.a. } & n.a. & n.a. & \multirow{2}{*}{ n.a. } & \multirow{2}{*}{ n.a. } & \multirow{2}{*}{ n.a. } & \multirow{2}{*}{0.992} & \multirow{2}{*}{0.109} \\
\hline & $30 \mathrm{kDa}$ & 5 & 0.965 & $<0.01$ & & 0.075 & 0.072 & & & & & \\
\hline \multirow[t]{2}{*}{$05 / 06 / 2015$} & $0.2 \mu \mathrm{m}$ & & 0.808 & $<0.05$ & \multirow[b]{2}{*}{ n.s. } & -0.007 & 0.115 & \multirow[b]{2}{*}{0.616} & \multirow[b]{2}{*}{0.174} & \multirow[b]{2}{*}{-0.02} & \multirow[b]{2}{*}{0.596} & \multirow[b]{2}{*}{0.098} \\
\hline & $30 \mathrm{kDa}$ & 5 & 0.925 & $<0.01$ & & 0.028 & 0.065 & & & & & \\
\hline \multirow[t]{2}{*}{$11 / 08 / 2015$} & $0.2 \mu \mathrm{m}$ & & 0.761 & $<0.05$ & \multirow[b]{2}{*}{ n.s. } & -0.062 & 0.056 & \multirow[b]{2}{*}{0.329} & \multirow[b]{2}{*}{0.092} & \multirow[b]{2}{*}{0.01} & \multirow[b]{2}{*}{0.339} & \multirow[b]{2}{*}{0.100} \\
\hline & $30 \mathrm{kDa}$ & 6 & 0.740 & $<0.05$ & & -0.035 & 0.061 & & & & & \\
\hline \multirow[t]{2}{*}{$27 / 08 / 2015$} & $0.2 \mu \mathrm{m}$ & & 0.869 & $<0.01$ & \multirow{2}{*}{ n.s. } & -0.200 & 0.045 & \multirow{2}{*}{0.382} & \multirow{2}{*}{0.078} & \multirow{2}{*}{0.00} & & \\
\hline & $30 \mathrm{kDa}$ & 6 & 0.856 & $<0.01$ & & -0.222 & 0.047 & & & & 0.382 & 0.078 \\
\hline
\end{tabular}

(B) Bacteria

\begin{tabular}{|c|c|c|c|c|c|c|c|c|c|c|c|c|}
\hline \multirow[b]{2}{*}{$(\mathrm{day} / \mathrm{mo} / \mathrm{yr})$} & \multirow{2}{*}{ Diluent } & \multirow{2}{*}{$\begin{array}{c}\text { Dilution } \\
\text { level }\end{array}$} & \multicolumn{2}{|c|}{ Linear fit } & \multirow{2}{*}{$\begin{array}{c}\text { Regresion } \\
\text { slopes } \\
p\end{array}$} & \multirow{2}{*}{$\mu$} & \multirow{2}{*}{$\pm \mathrm{SE}$} & \multirow{2}{*}{$g$} & \multirow{2}{*}{$\pm \mathrm{SE}$} & \multirow{2}{*}{$v$} & \multirow{2}{*}{$g+v$} & \multirow{2}{*}{$\pm \mathrm{SE}$} \\
\hline & & & $r^{2}$ & $p$ & & & & & & & & \\
\hline \multirow[t]{2}{*}{$19 / 05 / 2015$} & $0.2 \mu \mathrm{m}$ & 5 & 0.736 & $<0.1$ & \multirow[b]{2}{*}{ n.s. } & 0.502 & 0.194 & \multirow[b]{2}{*}{0.846} & \multirow[b]{2}{*}{0.293} & \multirow[b]{2}{*}{-0.30} & \multirow[b]{2}{*}{0.546} & \multirow[b]{2}{*}{0.165} \\
\hline & $30 \mathrm{kDa}$ & & 0.797 & $<0.05$ & & 0.546 & 0.165 & & & & & \\
\hline \multirow[t]{2}{*}{$05 / 06 / 2015$} & $0.2 \mu \mathrm{m}$ & 5 & 0.957 & $<0.001$ & \multirow[b]{2}{*}{ n.s. } & 0.313 & 0.042 & \multirow[b]{2}{*}{0.522} & \multirow[b]{2}{*}{0.064} & \multirow[b]{2}{*}{0.06} & \multirow[b]{2}{*}{0.586} & \multirow[b]{2}{*}{0.091} \\
\hline & $30 \mathrm{kDa}$ & & 0.933 & $<0.001$ & & 0.387 & 0.060 & & & & & \\
\hline \multirow[t]{2}{*}{$11 / 08 / 2015$} & $0.2 \mu \mathrm{m}$ & 6 & 0.873 & $<0.001$ & \multirow[b]{2}{*}{ n.s. } & 0.094 & 0.050 & \multirow[b]{2}{*}{0.429} & \multirow[b]{2}{*}{0.082} & \multirow[b]{2}{*}{0.31} & \multirow[b]{2}{*}{0.736} & \multirow[b]{2}{*}{0.152} \\
\hline & $30 \mathrm{kDa}$ & & 0.854 & $<0.001$ & & 0.239 & 0.092 & & & & & \\
\hline \multirow[t]{2}{*}{$27 / 08 / 2015$} & $0.2 \mu \mathrm{m}$ & 6 & 0.575 & $<0.1$ & \multirow[b]{2}{*}{ n.a. } & 0.053 & 0.080 & \multirow[b]{2}{*}{0.305} & \multirow[b]{2}{*}{0.131} & \multirow[b]{2}{*}{ n.a. } & & \\
\hline & $30 \mathrm{kDa}$ & & 0.241 & n.s. & & n.a. & n.a. & & & & n.a. & n.a. \\
\hline
\end{tabular}

427 Statistically significant values are shown in bold.

428 n.s., not significant; n.a., not available.

429

430 
Table 4

\begin{tabular}{|c|c|c|c|c|}
\hline $\begin{array}{c}\text { Date } \\
\text { (day/mo/yr) }\end{array}$ & Microbes & $\begin{array}{c}\mathrm{CB} \\
\left(\mu \mathrm{g} \mathrm{C} \mathrm{L}^{-1}\right)\end{array}$ & $\begin{array}{c}\mathrm{CP} \\
\left(\mu \mathrm{g} \mathrm{C} \mathrm{L}^{-1} \mathrm{~d}^{-1}\right)\end{array}$ & $\begin{array}{c}\mathrm{GL} \\
\left(\mu \mathrm{g} \mathrm{C} \mathrm{L}^{-1} \mathrm{~d}^{-1}\right)\end{array}$ \\
\hline \multirow[t]{3}{*}{$19 / 05 / 2015$} & Synechococcus & 0.06 & n.a. & n.a. \\
\hline & Bacteria & 4.71 & 2.36 & 3.98 \\
\hline & $\mathrm{HNF}$ & 0.81 & n.d. & n.d. \\
\hline \multirow[t]{3}{*}{$05 / 06 / 2015$} & Synechococcus & 0.11 & -0.001 & 0.07 \\
\hline & Bacteria & 9.78 & 3.06 & 5.10 \\
\hline & $\mathrm{HNF}$ & 0.64 & n.d. & n.d. \\
\hline \multirow[t]{3}{*}{$11 / 08 / 2015$} & Synechococcus & 0.66 & -0.04 & 0.22 \\
\hline & Bacteria & 6.22 & 0.59 & 2.67 \\
\hline & $\mathrm{HNF}$ & 0.75 & n.d. & n.d. \\
\hline \multirow[t]{3}{*}{$27 / 08 / 2015$} & Synechococcus & 0.34 & -0.07 & 0.13 \\
\hline & Bacteria & 3.10 & 0.16 & 0.94 \\
\hline & HNF & 0.87 & n.d. & n.d. \\
\hline
\end{tabular}

$433 \mathrm{CB}$, carbon biomass; CP, carbon production; GL, grazing loss; n.d., not determined; n.a., not available. 
436

437

Table 5

\begin{tabular}{crr}
\hline $\begin{array}{c}\text { Date } \\
(\text { day/mo/yr })\end{array}$ & $\begin{array}{c}\mathrm{Syn}_{\mathrm{CB}} / \mathrm{Bac}_{\mathrm{CB}} \\
(\%)\end{array}$ & $\begin{array}{c}\mathrm{Syn}_{\mathrm{GL}} / \mathrm{Bac}_{\mathrm{GL}} \\
(\%)\end{array}$ \\
\hline $19 / 05 / 2015$ & 1.3 & n.a. \\
$05 / 06 / 2015$ & 1.2 & 1.4 \\
$11 / 08 / 2015$ & 10.6 & 8.2 \\
$27 / 08 / 2015$ & 11.0 & 13.8 \\
\hline
\end{tabular}

438

n.a., not available.

439 
A: May \& Jun

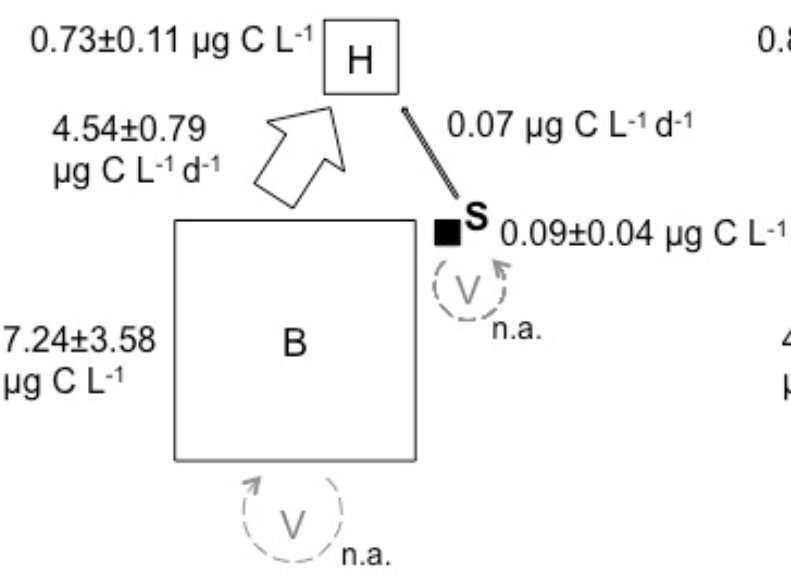

B: August (High abundance period)

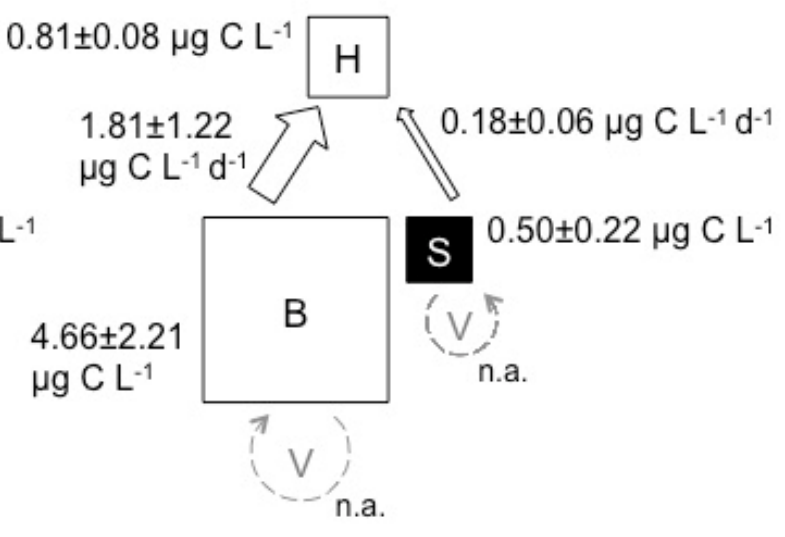

Figure 1. Takasu \& Nakano 